\title{
Applying of Cooperative Integrated Reading and Composition (CIRC) Strategy on Students' Reading Comprehension
}

\author{
Umar Al Faruq A Hasyim¹, Yeasy Agustina Sari2 ${ }^{*}$, Nurul Puspita3 \\ Institut Agama Islam Ma'arif NU Metro', Indonesia \\ Institut Agama Islam Negeri Metro', Indonesia \\ Universitas Islam Negeri Raden Intan Lampung3, Indonesia
}

Ⓨeasy120708@gmail.com*

\begin{abstract}
The article was to analyse Cooperative Integrated Reading and Composition (CIRC) Strategy Effective on student's reading comprehensio, especially in recount text. This research was conducted at tenth grade in second semester at tenth grade SMA 10 Bandar Lampung The design of this research was quantitative research. The subject of this research was 32 students at tenth grade of SMA 10 Bandar Lampung. The result of the research showed that the significant influence was clarified by the assumption of the level of the coefficients correlation between Cooperative Integrated Reading and Composition (CIRC) Strategy and students' reading comprehension which was signing positive. Directing to positive correlation means that if the level of Cooperative Integrated Reading and Composition (CIRC) Strategy is high, the level of students' reading comprehension is also high. In contrast, if the level of Cooperative Integrated Reading and Composition (CIRC) Strategy is low, the level of students' reading comprehension is also low. Moreover, based on the result of hypothesis testing result (table of correlations) demonstrated that $\mathrm{r}$ observed is higher than $\mathrm{r}$ table with $\mathrm{N}=32$, it can be looked at significant either for level $5 \%$ or $1 \%$. In the table also demonstrated that the level of significant was $1,696<10,56>2,040$. It means that the correlation between Cooperative Integrated Reading and Composition (CIRC) Strategy and students' reading comprehension was significant.
\end{abstract}

Keyword: Reading Comprehension, CIRC Strategy, Reading and Composition (CIRC) Strategy

How to cite

Hasyim, U., Sari, Y., \& Puspita., N. (2020). Applying Cooperative Integrated Reading and Composition (CIRC) Strategy on Students' Reading Comprehension. Anglophile Journal, 1(1). p.41-47.

This is an open access article under the CC BY SA license https://creativecommons.org/licenses/by-sa/4.0/

Published by CV. Creative Tugu Pena

\section{INTRODUCTION}

English as first language in Indonesia is a compulsory subject at formal education settings, from Senior High School up to University. Recently, English has also been introduced to students of elementary school, starting at first grade (Sari \& Suhono, 2017). The curriculum states that SMA/MA students should be able to use the language in informational level that is expected to access knowledge by the language skills. Based on the reason that students are expected to get information for increasing their knowledge which is mostly written in English. Reading is a process used for learning that inseparable from any kinds of learning including language learning. In this activity, students are in the process of comprehending the content of the text given by the teacher (Suhono, S \& Sari, D. 
(2020). In the process, the students do some task that are given such as finding certain information and main ideas from the texts and gathering the general description from the content of the texts (Hahnel et al., 2018: Alkhaleefah, 2016). Reading to students can help to expand their vocabularies and writing skills, as well as to interest them in new ideas.

To gather the knowledge from the text, it is important for students to have a good reading comprehension. Without comprehension, reading would be empty and meaningless (Rahmadani, 2017; Suardi \& Geri, 2017; Fitriyah, 2020). Comprehension is not only intended to know what the letters stand for, but also involved power of fully understanding (Duncan et al., 2020; Sorenson Duncan; 2020). Reading comprehension requires motivation, mental frameworks for holding the ideas, concentration and good study techniques (Mohseni \& Ahmadi, 2017). There are many ways to be good at reading such as; the readers should know the purpose in reading, they also should have of type of material they are reading, and kinds of learning strategies can also be used in reading that can help them in comprehending the reading text.

The main problem among the tenth grade at SMA 10 Bandar Lampung that makes the students do not like with reading subject is uninteresting teaching strategy which is used by the teacher. It means that the students have low in reading ability. Most of the students' often feature difficulties in recognizing and appropriately applying background knowledge, poor decoding and word recognition skills, limited vocabulary knowledge, and underdeveloped reading fluency. Problems of reading ability, especially in mastering recount text. It caused the teacher didn't use media, games, or strategy in teaching learning process. so the process of learning was passive, the effect the students fell boring, lazy, and most of them were busy with themselves. Based on the data pra-survey students' reading result above show that 3 (9\%) student who scored high score or can achieve have passed and 29 (91\%) failed from the Minimum Mastery Criterion (KKM), so far from the target. In fact, not everyone is good at reading, in general, students still have difficulty in comprehending the idea in a reading text. Found that students had difficulty in comprehending reading texts. Some factors that cause the students, difficulties in comprehending reading texts she found in her research, are: (1) interpreting the new vocabulary, (2) unphrasing reading, (3) interest in the materials( the text ), (4) the lack of scemata/background knowledge about the text, (5) ignoring reading technique. 7 These conditions show that reading is not a simple task to do for some people. For those people reading can be a painnful and boring activity. There are many factors that might influence students' problem in reading. One may have difficulties to comprehend a passage because of some problems such as unfamiliar code in which the text is expressed, the amount of previous knowledge that reader brings to the text, the complexity of the concept expressed, and vocabulary knowledge.

However, the researcher assumes that one the most important factors in the reading startegy used in the class. The students are lack of effective reading strategy. As the way out of this problem, the readers need a more creative reading strategy to overcome the problems. They need to be familiar with many kinds of reading strategy that can help them comprehend the text much better. Among many techniques that can be applied in teaching reading comprehension is Cooperative Integrated Reading Composition (CIRC) Strategy (Hayatina \& Fajrina, 2018; Ghasemi \& Baradaran 2018). The Cooperative Integrated Reading Composition Strategy technique was developed to improve reading fluency by providing an oral model of the passage at the same time that the student is attempting to read it (Kamdideh et al., 2019: Wahyuningsih \& Citraningrum, 2019; Wulandari et al., 2020). When using Cooperative Integrated Reading Composition Strategy, one student is paired up with the teacher. The teacher and student read together at the student's independent reading level. Teachers can also use material that the student 
has read before. The teacher should make sure the book is of high interest of the student so they will be engaged the entire time they are reading.

There were many scholars who discussed about Cooperative Integrated Reading Composition trategy, the first schoolar was Rahmawati (2018), entitle The Effect Of CIRC Strategy And Achievement Motivation Toward Students' Reading Comprehension. Their findings concluded that there is an effect of the interaction between the teaching strategy applied and students' achievement motivation toward their reading comprehension; there is a significant difference in reading comprehension between students with high achievement motivation who are taught by using CIRC strategy and those taught with the conventional strategy. The second schoolar was Mubarok (2017), Cooperative Integrated Reading And Composition (CIRC) And Reading Motivation: Examining The Effect On Students' Reading Ability. Their findings concluded that started from the similar level of reading ability the students of the experimental group performed better on reading ability than the control group. It indicates that CIRC increases students' reading ability better than the conventional teaching strategy.

Based on some overview the previous study above the current research study was different from previous study above, this study focused on students' reading comprehension, besides that the research subjects were tenth grade of SMA 10 Bandar Lampung. And this research have similarities in this research that is use Cooperative Integrated Composition and Reading Strategy. Because of that the researcher would to using Cooperative Integrated Composition and Reading (CIRC) Strategy in more specific in recount text to help students' reading Comprehension using Cooperative Integrated Composition and Reading Strategy. In order the student can improve their reading Comprehension used this strategy with good and more maximal. In CIRC, students work in group to work cooperatively on various activities such as reading in pair, identifying the main story element, doing vocabulary and summarization activities, and practicing reading comprehension and creative writing.

When first starting out with this strategy, the teacher should read a little louder and faster than the student. Once the student seems to be gaining their confidence and fluency is improving, the teacher can start to read quieter and a little behind the student. If the student seems to be having trouble, the teacher should help the student in a firm matter. The student can take over this role when they feel comfortable doing so based on explanation above the researcher analyse applying of Cooperative Integrated Reading And Composition (CIRC) Strategy Toward Students' Reading Comprehension In Recount Text at Tenth Grade of at tenth grade SMA 10 Bandar Lampung.

\section{METHOD}

The researcher used the quantitative research. In experimental design, the researcher used two classes which consists of control group pretest posttest design. This design is used to compare the condition before and after treatment with control group. The sample of this research was 64 students that consist of 32 students from experimental class ( $x$ IPS) and 32 students from control class ( $x$ IPA). In collecting data the researcher used test, interview and documentation. The type of this test is objective test. It is multiple choice test. The researcher prepared 15 items. Each item consist of four option a,b,c, and d. multiple choice test. The writer prepared 15 items. Each item consists of four option a. b, c, and $d$. Pre test given before treatment, to know far the students overcome in reading comprehension. Post test given to students after treatment, it is to know the result of students achievement through CIRC Strategy. Post test given to students after treatment, it is to know the result of students achievement through CIRC Strategy. In interview process the interviewer has to conduct collecting data with doing interaction or communication directly. But, it can be conducted face to face or through via electronic. The researchers get from process of observation, interviews, field notes and file from institution. In this 
study, the researcher know of consisting of teaching and learning reading activities. The next step, the researcher processes the data. In order To know how level of influence of the prior knowledge toward the student's reading ability. The researcher calculated the students score by using statistic calculation of t- test formula with significant degree $0,05 \%$ and $0,025 \%$. Pre-test and post-test score of both groups was computed using groups.

\section{RESULT AND DISCUSSON}

In this research, there are two variables, the independent variable that is CIRC Strategy (X), and the dependent variable that is students' reading comprehension (Y). The variables were tested by using calculation of linier regression analysis to investigate whether there is effectiveness of independent variable (CIRC Strategy) toward dependent variable (students' reading comprehension). The calculation demonstrated that there is any positive and significant effectiveness of CIRC Strategy toward students' reading comprehension.

Moreover, the positive effectiveness was clarified by the assumption of the level of the coefficients correlation between CIRC Strategy and students' reading comprehension which was signing positive. Directing to positive correlation means that if the level of CIRC Strategy is high, the level of students' reading comprehension is also high. In contrast, if the level of CIRC Strategy is low, the level of students' reading comprehension is also low. Moreover, based on the result of hypothesis testing result (table of correlations) demonstrated that $r$ observed is higher than $r$ table with $\mathrm{N}=32$, it can be looked at significant either for level $5 \%$ or $1 \%$. In the table also demonstrated that the level of significant was $1,696<10,56>2,040$. It means that the effectiveness between CIRC Strategy and students' reading comprehension was significant.

Furthermore, the result of this research the background knowledge or what students already know about the content is one of the strongest indicators of how well they will learn new information relate to the content: students' reading comprehension will be more easily retained of how well the student's background knowledge about the content. In this view, the founding of this research is in line which indicates that when the student's CIRC Strategy is high, the student's reading comprehension is also high. Through CIRC strategy, students' social interaction is built, students can collaborate with the others and create a good communication by respecting other's thought. Learning in a group do have the positive impact in learning, both academically and emotionally. As a Christian teacher, introducing the students to face the real world by learning is challenging. Future students will be expose with worldly perspective about learning in a community. Knowledge can be accessed easily through the technology which caused the students to become passive in learning. The worst is when the students are reluctant to communicate with other and become ignorant. In Christian sense, man is blessed with love, kindness, and responsibility.

The CIRC strategy provides a learning environment where students understand their role in the group and to work as a team based on their ability. Students can learn how to be responsible for the group to achieve the goal together. Therefore, teacher supposed to refer students to God's reflection who each of them is unique and they need to build a community who can help students in learning. The real action from the researcher which reflect the role of teacher was happen when the teacher talking eye to eye with S4. The researcher asked the student and has a good conversation about the lesson and S4's personal background. Realize or not, this action could bring impact for the student, because the researcher care for S4 and S4's progress in learning.

Some research finding, for instance Mustafa \& Samad (2015) that focus on Cooperative Integrated Reading and Composition Technique for Improving Content and Organization in Writing. Their findings concluded that the students' writing improved 
in content and organization. It was a more effective technique to enhance students' writing skill than the traditional methods (in this case, a mixture of Grammar Translation Method and Audio Lingual Method) since it tapped the students' cultural backgrounds and made these experiences more meaningful, relevant, and interesting to the students. The fourth scholar was Saputra, M. H., Sutarsyah, C., \& Yufrizal, H. (2018). Modified Cooperative Integrated Reading Comprehension (CIRC) through Genre-Based Approach to Promote Students' Reading Achievement. Their findings concluded that there is a significant difference of students' reading comprehension achievement after being taught by using CIRC and GBCIRC. The significant difference can be seen in the result of students' achievement. The reason why there is a significant difference might be because the students have sufficient schemata to reactivate their prior knowledge before reading. Genre-Based Cooperative Integrated Reading Comprehension (GBCIRC) is effective for students in order to improve students reading achievement.

This research also explained that the theory of the effectiveness of CIRC Strategy on students' reading comprehension was prevailed in the Tenth grade students at SMA 10 Bandar Lampung. In other word, the result of the research may vary on other educational institutions. It depends on several factors such as condition, situation, research setting, and subject of the research. The differences of ability and other uniqueness of each student also becomes a decisive factor which causes the difference result of the research in the other educational institutions.

\section{CONCLUSION}

CIRC Strategy is one of the technique that comes from active learning, which explained this technique use to practice a skills or procedure with a friend by practicing exercise repeatedly which use the information to learn it. After discussing this research, it was inferred that CIRC Strategy related to such prior experience and knowledge in knowledge of reading itself, contents, topics, concepts, and text structure especially when the students bring it in reading process. Although the correlation which has been found in this research was categorized in fair category, the correlation of CIRC Strategy and students' reading comprehension is still positive and significant. It was used by the writer as the base in analyzing data by using regression analysis to predict how level of influence of CIRC Strategy on increasing students' reading comprehension. Moreover, based on the result of hypothesis testing result (table of correlations) demonstrated that $r$ observed is higher than $\mathrm{r}$ table with $\mathrm{N}=32$, it can be looked at significant either for level 5 $\%$ or $2,5 \%$. In the table also demonstrated that the level of significant was $1,696<10,56>$ 2,040 . The significant influence is $10,56 \%$. It means that there is any positive and significant the effectiveness of CIRC Strategy on students' reading comprehension. The higher CIRC Strategy students have, the higher students' reading comprehension students get. Furthermore, when conducting this research, the writer found an interesting point which demonstrated that student's tendency and interest to certain topics also has a crucial effectiveness students' reading comprehension. The students' reading comprehension will be gained well if it is done with fun by the topic is appropriate with their tendency or interest.

\section{ACKNOWLEDGEMENT}

The author would like thank to the various parties who have helped in completing this research, especially to teachers the teachers. Thank for the team in collaboration research who conducted learning innovation during COVID-19.

\section{AUTHOR CONTRIBUTION STATEMENT}

This research was conducted by two authors from different colleges. YAS was intended to help from the beginning in preparing until the end in reporting of research 
even UA and NP as supporting research and supporting of the field more give contribution to collect datas. The authors had participated in the research and approved the final version of the manuscript.

\section{REFERENCES}

Alkhaleefah, T. A. (2016). Taxonomies in L1 and L2 reading strategies: A critical review of issues surrounding strategy-use definitions and classifications in previous thinkaloud research. The Reading Matrix: An International Online Journal, 16(2), 162-226. Google Scholar

Duncan, T. S., Mimeau, C., Crowell, N., \& Deacon, H. (2020). Not all sentences are created equal: Evaluating the relation between children's understanding of basic and difficult sentences and their reading comprehension. https://doi.org/10.1037/edu0000545

Fitriyah, I. (2020, May). Students' Reading Comprehension: Between the Effectiveness of Interactive Approach, Reading Habit and Self-Actualization. In International Conference on English Language Teaching (ICONELT 2019) (pp. 37-41). Atlantis Press. https://dx.doi.org/10.2991/assehr.k.200427.009

Ghasemi, Z., \& Baradaran, A. (2018). The Comparative effect of student team-achievement division and cooperative integrated reading and composition on EFL learners' speaking complexity. International Journal of Applied Linguistics and English Literature, 7(3), 67-72. http://dx.doi.org/10.7575/aiac.ijalel.v.7n.3p.67

Hahnel, C., Goldhammer, F., Kröhne, U., \& Naumann, J. (2018). The role of reading skills in the evaluation of online information gathered from search engine environments. Computers in Human Behavior, 78, 223-234. https://doi.org/10.1016/j.chb.2017.10.004

Hayatina, M., \& Fajrina, S. A. (2018). Cooperative Integrated Reading Composition to improve pupils' reading comprehension achievement and motivation. Journal of Research, Policy \& Practice of Teachers and Teacher Education, 8(2), 29-37. https://doi.org/10.37134/jrpptte.vol8.no2.4.2018

Kamdideh, Z., Vaseghi, R., \& Talatifard, S. (2019). The Effects of'Reciprocal Teaching of Reading'and'Cooperative Integrated Reading and Composition'on the Reading Comprehension of Iranian EFL Intermediate Students. Theory and Practice in Language Studies, 9(9), 1111-1117. http://dx.doi.org/10.17507/tpls.0909.06

Mohseni Takaloo, N., \& Ahmadi, M. R. (2017). The effect of learners' motivation on their reading comprehension skill: A literature review. International journal of research in English education, 2(3), 10-21. Google Scholar

Mubarok, H., \& Sofiana, N. (2017). Cooperative Integrated Reading and Composition (CIRC) and Reading Motivation: Examining The Effect on Students' Reading Ability. Lingua Cultura, 11(2), 121-127. Google Scholar

Mustafa, F., \& Samad, N. M. A. (2015). Cooperative Integrated Reading and Composition Technique for improving content and organization in writing. Studies in English Language and Education, 2(1), 29-44. Google Scholar

Rahmadani, A. N. (2017). The use of Small Group Work techniques for improving reading comprehension. English Education Journal, 8(1), 125-135. Google Scholar

Rahmawati, L. R. (2018). The Effect Of Circ Strategy And Achievement Motivation Toward Students'reading Comprehension. Jurnal Pendidikan dan Pembelajaran Bahasa Indonesia, 7(1). Google Scholar

Sari, Y. A., \& Suhono, S. (2017). Applaying Transition Action Detail Strategy on Written Text of EFL Young Learners. Jurnal Iqra': Kajian Ilmu Pendidikan, 2(1), 1-24. https://doi.org/10.25217/ji.v2i1.86 
Saputra, M. H., Sutarsyah, C., \& Yufrizal, H. (2018). Modified Cooperative Integrated Reading Comprehension through Genre Based Approach to Promote Students' Reading Achievement. U-JET, 7(5). http://dx.doi.org/10.23960/jpp

Sorenson Duncan, T., Mimeau, C., Crowell, N., \& Deacon, S. H. (2020). Not all sentences are created equal: Evaluating the relation between children's understanding of basic and difficult sentences and their reading comprehension. Journal of Educational Psychology. https://psycnet.apa.org/doi/10.1037/edu0000545

Suhono, S \& Sari, D. (2020). Developing Students' Worksheet Based Educational Comic for Eleventh Grade of Vocational High School Agriculture. Anglophile Journal, 1(1), 2940

Suardi, S., \& Geri, R. E. (2017). the use of directed reading thinking activity strategy through lesson study activity toward students'reading comperhension. ideas: Journal on English Language Teaching and Learning, Linguistics and Literature, 5(2). http://dx.doi.org/10.24256/ideas.v5i2.27

Varisoglu, B. (2016). Influence of Cooperative Integrated Reading and Composition Technique on Foreign Students' Reading and Writing Skills in Turkish. Educational Research and Reviews, 11(12), 1168-1179. Google Scholar

Wahyuningsih, A., \& Citraningrum, M. (2019). The Effectiveness of The Cooperative Integrated Reading and Composition (CIRC) and Preview Question Read Reflect Recite Review (PQ4R) on Reading Comphrehension Skill. Indonesian Journal on Learning and Advanced Education (IJOLAE), 1(1), 26-36. https://doi.org/10.23917/ijolae.v1i1.7383

Wulandari, U. N., Ansari, K., \& Hadi, W. (2020). The Effect of Cooperative Learning Models and Learning Motivation towards the Skills of Reading Students in Public Elementary School 101883 Tanjung Morawa Sub-district. Budapest International Research and Critics in Linguistics and Education (BirLE) Journal, 3(2), 1209-1219. https://doi.org/10.33258/birle.v3i2.1054

Copyright Holder :

(C) Hasyim, U., Sari, Y., \& Puspita., N. (2020)

First Publication Right :

(C) Anglophile Journal

This article is under:

CC BY SA 